\title{
TOWARDS MINIMUM PROCEDURAL GUARANTEES FOR THE DEFENCE IN CRIMINAL PROCEEDINGS IN THE EU
}

\section{INTRODUCTION}

A critical observer would not deny that the practice of European Union ('EU') policy making in the field of criminal law in the past decade since the implementation of the Tampere Programme has been mainly repressive and prosecution-oriented. ${ }^{1}$ The idea of introducing a set of common (minimum) rules, guaranteeing the rights of defence at a EU-wide level, has not been accorded the same attention as the introduction of instruments aimed at improving the effectiveness of crime-fighting. What does this mean for the future of EU criminal policy? Will the EU succeed in the coming years in developing an area where freedom, security and justice are truly balanced? According to several authors, to date the EU has evolved in the opposite direction. As one observer put it:

[I]f Procedural Criminal Law arises from the application of Constitutional Law, or indeed if it may be described as "a seismograph of the constitutional system of a State", then as a consequence the Procedural Criminal Law of the European Union shows the extent of the Democratic Rule of Law, of the existence of a true "Rechtsstaat", within an integrated Europe. This situation may be qualified as lamentable, as the main plank of the EU's criminal justice policy relates to the simplification and the speeding up of police and judicial cooperation - articles 30 and 31 of the Treaty of the EU—but without at the same time setting an acceptable standard for fundamental rights throughout a united Europe. ${ }^{2}$

Despite this negative evaluation, there is still hope for effective results in this field in the coming years. Some important action has already been taken. A first symbolic step was the signing of the Charter of Fundamental Rights in December 2000 by the European Commission, the Council and Parliament. ${ }^{3}$ Following the coming into force of the Lisbon Treaty in 2009, the provisions of the Charter now have binding legal force. Secondly, on 28 April 2004 an ambitious Proposal for a Council Framework Decision on certain procedural rights in criminal proceedings throughout the European Union was submitted by the European Commission ('2004 Proposal'). ${ }^{4}$ Although after years of (political) disagreement the Proposal was eventually abandoned in 2007, the EU has renewed its ambition to strive for minimum procedural rights. In its Resolution of 30 November $2009^{5}$ the Council endorsed the Roadmap for strengthening procedural

1 See, inter alia, M Anderson, 'Law enforcement cooperation in the EU and fundamental rights protection' in M Martin (ed), Crime, rights and the EU: the future of police and judicial cooperation (Justice 2008) 105-120; E Cape, J Hodgson, T Prakken and T Spronken (eds), Suspects in Europe, procedural rights at the investigative stage of the criminal process in the European Union (Intersentia 2007) 2-3.

${ }^{2} \mathrm{~K}$ Ambos, 'Mutual recognition versus procedural guarantees?' in M de Hoyos Sancho (ed), Criminal proceedings in the European Union: essential safeguards (Lex Nova 2008) 25.

${ }^{3}$ Charter of Fundamental Rights of the European Union, OJ C, 18 December 2000, 364/1.

${ }^{4}$ Commission Proposal for a council framework Decision on certain procedural rights in criminal proceedings throughout the European Union COM(2004)328 final (28 April 2004).

5 Council of the European Union, Resolution of 30 November 2009 on a Roadmap for strengthening procedural rights of suspected or accused persons in criminal proceedings OJ C 295/1, 4 December 2009. 
rights of suspected or accused persons in criminal proceedings ('the Roadmap') as the basis for future action. The Resolution clearly states that action should be taken at EU level in order to strengthen the rights of suspected or accused persons in criminal proceedings. Furthermore, the Resolution describes the rights included in the Roadmap ${ }^{6}$ as fundamental procedural rights to which absolute priority should be given. The Roadmap was later incorporated in the 2009 'Stockholm Programme', ${ }^{7}$ which sets out the EU's priorities for the area of justice, freedom and security for the period 20102014.

Against this background, this article examines the current state of procedural rights for suspects and defendants in criminal proceedings in the EU. The analysis is structured around three central questions. Firstly, what is the importance of such rights in the EU? Secondly, what procedural safeguards currently exist in the Member States, and are the fundamental procedural rights in criminal proceedings as provided for by the European Convention of Human Rights ('ECHR') effectively guaranteed in the criminal justice systems of the EU? Finally, if the answer to the previous questions suggest the need for EU action in this field, what steps have already been taken in this regard and what does the future hold?

\section{THE IMPORTANCE OF MINIMUM PROCEDURAL GUARANTEES FOR THE DEFENCE IN CRIMINAL PROCEEDINGS THROUGHOUT THE EU}

An initial question in any debate on minimum procedural guarantees in criminal proceedings is whether such a debate is at all useful. Why should Member States accord attention to this issue? Would it not suffice to refer to the ECHR as the main mechanism for preserving fundamental rights in Europe? Could the EU bring added value and, if so, how? Does the mutual recognition doctrine not imply a basic level of trust between EU's Member States? The answer to these and related questions centres on two main themes: (a) the inadequacy of the ECHR framework; and (b) the mutual recognition doctrine.

\section{A. The Inadequacy of the ECHR Framework}

Doubts about whether the ECHR and the European Court for Human Rights ('ECtHR') are able to offer sufficient protection to suspects and defendants in criminal proceedings are not ill-founded. The ECHR is implemented to very differing standards in the Member States and there are many violations. The number of applications is growing every year and the ECtHR is seriously overloaded: articles 5 and 6 of the Convention, which guarantee the right to liberty and security (article 5), and the right to a fair trial in civil and criminal proceedings (article 6), are the most commonly cited in applications. Moreover, Member States have not always amended their legislation to adapt them to the condemnatory judgements of the ECtHR, which - in essence - are not of an enforceable nature.

6 The Roadmap calls for action to be taken around 5 issues: Translation and Interpretation; Information on Rights and Information about the Charges; Legal Advice and Legal Aid; Communication with Relatives, Employers and Consular Activities; Special Safeguards for Suspected or Accused Persons who are Vulnerable; and a Green Paper on Pre-Trial Detention.

7 An open and secure Europe serving and protecting the citizen, OJ C, 4 May 2010, 115.

\section{CAMBRIDGe JOURNALS}


Further, the ECHR jurisprudence does not contain any explicit imperative on the rules of evidence. ${ }^{8}$ The admissibility of evidence is primarily governed by the rules of domestic law, provided that they respect the rights and freedoms guaranteed by the Convention. It often remains difficult to conclude from ECHR decisions whether, or to what extent, the use of illegally or unfairly obtained evidence constitutes a violation.

The fundamental question, however, relates to whether the procedural rights provided for by the ECHR are effectively implemented in the EU Member States. At this point, an important distinction should be made between the mere legal recognition of these rights in the criminal justice systems of the Member States and their (effective) implementation in everyday practice. The results of a recent study of this practice, discussed further below raise serious doubts as to whether the practice in all Member States accords with the ECHR standard.

The preamble to the 2009 Council Resolution endorsing the Roadmap on procedural rights seems to confirm this concern, although in a more subtle way: 'the Convention, as interpreted by the European Court of Human Rights, is an important foundation for Member States to have trust in each other's criminal justice systems and to strengthen such trust. At the same time, there is room for further action on the part of the European Union to ensure full implementation and respect of Convention standards, and, where appropriate, to ensure consistent application of the applicable standards and to raise existing standards'.

\section{B. Mutual Recognition and Minimum Procedural Guarantees}

Mutual recognition presupposes that the competent authorities of the Member States trust the criminal justice systems of the other Member States. For the purpose of enhancing mutual trust within the European Union, it is important that, complementary to the Convention, there exist European Union standards for the protection of procedural rights which are properly implemented and applied in the Member States ${ }^{9}$.

Since the European Council meeting in Tampere in $1999,{ }^{10}$ the concept of mutual recognition of judicial decisions has been the cornerstone of judicial cooperation in civil and criminal matters and has served as a catalyst for harmonisation of the criminal law of the EU Member States. It was given practical expression in the criminal law context in a well-structured twenty-four measure programme adopted in $2001,{ }^{11}$ with mutual recognition featuring high on the EU's justice and home affairs agenda ever since. A number of legislative and other steps have subsequently been taken to achieve mutual recognition of certain decisions in criminal matters within the EU. ${ }^{12}$

${ }^{8} \mathrm{~S}$ Gless, 'Mutual recognition, judicial inquiries, due process and fundamental rights' in J Vervaele (ed), European evidence warrant: transnational judicial enquiries in the EU (Intersentia 2005) 124.

9 Preamble to the 2009 Council Resolution, endorsing the Roadmap on procedural rights.

${ }^{10}$ European Council, Presidency Conclusions, 15-16 October 1999.

${ }^{11}$ Council of the EU, Programme of measures to implement the principle of mutual recognition of judicial decisions in criminal matters, OJ C 12 of 15.1.2001.

${ }_{12}$ Council Framework Decision of 13 June 2002 on the European arrest warrant and the surrender procedures between Member States, OJ L 190/1 of 18.7.2002; Council Framework Decision 2003/577/JHA of 22 July 2003 on the execution in the European Union of orders freezing property or evidence, OJ L 196 of 2.8.2003; Council Framework Decision 2005/214/JHA of

\section{CAMBRIDGE JOURNALS}


While the principle of mutual recognition has been known and applied in the context of Europe's internal market for decades (by establishing free movement of goods and mutually recognising product standards), ${ }^{13}$ transferring this principle to the setting of criminal proceedings is no simple matter. The free movement of goods cannot be compared to the free movement of evidence or data in the context of a criminal prosecution. This is not only due to the fact that evidence or data to be used in criminal proceedings cannot be extracted or 'exported' as a 'final product' from the general context of its legal order, with its respective particularities relating to the way it is gathered, without bringing about changes or loss of probative value. ${ }^{14}$ At least as crucial is the fact that the personal freedoms of EU citizens are at stake in this field. This requires a specific approach.

The Tampere version of the mutual recognition principle was something of a novum, in that it requires the recognition and execution of judicial decisions from other Member States without a national, judicial test of their lawfulness or legitimacy. ${ }^{15}$ The logical implication of this is mutual recognition a priori that the foreign process in question meets all of the requirements that flow from the rule of law, as understood by the executing State. ${ }^{16}$

It is a logical conclusion therefore that, given the sensitivities surrounding sovereignty and feelings of superiority with regard to one's own national criminal procedures, mutual recognition in the field of judicial cooperation in criminal matters is only feasible if all States can rely on decisions taken abroad meeting at least the minimum safeguards provided byt their own procedures. ${ }^{17}$ Hence it is an indisputable fact that effective judicial cooperation in criminal proceedings according to the mutual recognition doctrine is partly dependent on a commonly accepted level of trust between

24 February 2005 on the application of the principle of mutual recognition to financial penalties, OJ L 76 of 22.3.2005; Council Framework Decision 2006/783/JHA of 6 October 2006 on the application of the principle of mutual recognition to confiscation orders, OJ L 328 of 24.11.2006; Council Framework Decision 2008/675/JHA of 24 July 2008 on taking account of convictions in the Member States of the European Union in the course of new criminal proceedings, OJ L 220 of 15.8.2008; Council Framework Decision 2008/909/JHA of 27 November 2008 on the application of the principle of mutual recognition to judgments in criminal matters imposing custodial sentences or measures involving deprivation of liberty for the purpose of their enforcement in the European Union, OJ L 327 of 5.12.2008; Council Framework Decision 2008/947/JHA of 27 November 2008 on the application of the principle of mutual recognition to judgments and probation decisions with a view to the supervision of probation measures and alternative sanctions, OJ L 337, 16.12.2008; Council Framework Decision 2008/978/JHA of 18 December 2008 on the European evidence warrant for the purpose of obtaining objects, documents and data for use in proceedings in criminal matters, OJ L 350 of 31.12.2008. In addition the Commission produced a green paper on the principle of mutual recognition: Communication from the Commission to the Council and the European Parliament on the mutual recognition of judicial decisions in criminal matters and the strengthening of mutual trust between Member States COM(2005)195 (19 May 2005).

13 Case 120/78 Rewe-Zentral AG v Bundesmonopolverwaltung für Branntwein [1979] ECR $469 . \quad{ }^{14} \mathrm{~K}$ Ambos, l.c., 31.

${ }^{15} \mathrm{C}$ Brants 'Procedural safeguards in the European Union: too little, too late?' in J Vervaele (ed), oc, 106.

16 For further analysis, see G Vermeulen, 'Mutual recognition, harmonisation and fundamental (procedural) rights protection', in M Martin (ed), Crime, rights and the EU: the future of police and judicial cooperation (Justice 2008) 89-104.

17 Brants (n 13).

\section{CAMBridge JOURNALS}


the competent national authorities, which in turn requires the presence of a common set of minimum procedural guarantees for the defence.

This fact is all the more so given the latest evolution in the field of judicial cooperation in criminal proceedings in the EU. In the view of the Commission, traditional judicial cooperation in criminal matters will eventually be replaced (entirely) by the mutual recognition principle, which should smooth the way for inter-State assistance and remove superfluous formalities from all methods of cooperation. Combined with the continuing shift from the traditional 'locus regit actum' rule to the 'forum regit actum' principle, this would imply that the execution of mutually recognised warrants would increasingly be determined by the procedural rules of the issuing/requesting State. This evolution implies that the EU is a considerable step closer to a genuine free movement of evidence between Member States. ${ }^{18}$ The link with respect for minimum procedural safeguards throughout the EU is evident. The evolution towards a free movement of evidence would be detrimental for the legal position of suspects and defendants alike without the guarantee of an adequate level of procedural protection. Furthermore, the effectiveness of the system (ie a smooth execution of the 'warrants') would be seriously hindered if the current differences between members in regard of procedural rights were to be maintained. The executing Member State would have to make a case by case comparison between the procedural rules of the issuing Member State and its own fundamental principles of law. It cannot be predicted how Member State would deal with such an exercise. One thing is sure though. A minimum standard of procedural safeguards, taking into account both the ECHR (and its case law) and the fundamental principles of each Member State, would hugely diminish potential obstacles in applying the 'forum rule'.

III. PROCEDURAL SAFEGUARDS IN CRIMINAL PROCEEDINGS THROUGHOUT THE EU: THE CURRENT STATE OF AFFAIRS ${ }^{19}$

In 2005, the Commission arranged for a study to be carried out on procedural rights in the EU, in order to comply with the The Hague Programme's call for studies on the existing levels of safeguards in the Member States. ${ }^{20}$ In 2008-09 a new study was carried out as a follow-up report to the 2005 study. The goal of the new study was to obtain up to date information on the level of provision of procedural rights in the Member States that can provide a lead for a possible new Commission legal initiative on

${ }^{18}$ It should be noted in this respect that the Convention of 18 December 1997 on mutual assistance and cooperation between customs administrations, OJ C 24/1, 23.01.1998 (Napels II Convention) - which can be applied between judicial authorities in criminal investigations (art 3) - not only provides that 'the requested authority shall agree to comply [with]a particular procedure in response to a request, provided that that procedure is not in conflict with the legal and administrative provisions of the requested Member State' (art 9(6)) but also foresees a far-reaching framework for using information in a broad sense ('... findings, certificates, information documents, certified true copies and other papers ...') acquired in the requested State as evidence in accordance with the national law of the requesting State (art 14).

19 This section draws on T Spronken, G Vermeulen, D de Vocht and L van Puyenbroeck, EU Procedural Rights in Criminal Proceedings (Maklu 2009) 116, in particular chapter 1.

${ }^{20}$ TNBM Spronken and M Attinger, Procedural Rights in criminal proceedings: Existing Level of Safeguards in the European Union, funded and published by the European Commission 12 December 2005, available at $<$ http://arno.unimaas.nl/show.cgi?fid=3891>.

\section{CAMBridge JOURNALS}


the matter. The report aimed at providing an overview of the status quo of four fundamental procedural rights in criminal proceedings in the EU Member States: the right to information; the right to legal advice; the right to legal assistance free of charge; and the right to translation and interpretation of documents. ${ }^{21}$

This article first offers an analysis of these procedural rights which the ECHR provides for, as dealt with in recent case law of the ECtHR Secondly, an overview is given of the extent to which these procedural rights are guaranteed in the formal legislation of each EU Member State. This overview was obtained through an extensive questionnaire which was sent out in 2009 to all twenty-seven EU Member States. ${ }^{22}$ The questionnaire also included questions on how the examined procedural rights are dealt with in the Member States within procedures concerning the European Arrest Warrant ('EAW') and other mutual recognition instruments. ${ }^{23}$ The right to information was dealt with in the questionnaire as an overarching horizontal issue and not as a separate right, as is the case for the analysis of the ECtHR case law. The conclusions drawn (referred to below as 'the study') are based on the answers as provided for by the representatives of the Ministries of Justice of the Member States. It should be noted that the project team did not carry out any research on the accuracy of these answers.

\section{A. Analysis of the ECHR Case Law}

\section{Right to Information}

a) Situations giving rise to the Right to Information

The right to information is considered to be a crucial aspect of the overall right to defend oneself. At the level of the ECHR both arrested and not arrested persons are entitled to receive information on the nature and cause of the accusation against them. ${ }^{24}$ Additionally, in case of an arrest, the reasons for the arrest become subject to the right to information. ${ }^{25}$

\section{b) Timing}

Articles 5(3) and 6(3)(a) ECHR require information to be delivered promptly. No further specification is made in the Convention as to what constitutes 'promptly'. Similarly, the 2004 Proposal refers in its article 14.1 to an 'immediate right'.

\section{c) Means}

The ECHR does not give any indication as to the means to be used to provide the information. The European Commission prefers written to oral information and thus has suggested in its 2003 Green Paper that Member States should be required to inform

21 Each of these rights is included in the Roadmap on procedural rights and was identified as a fundamental procedural right in the Council Resolution of November 2009 endorsing the Roadmap.

22 All Member States replied to the questionnaire except for Malta, so the conclusions are based on the information given by 26 Member States.

${ }_{23}$ T Spronken, G Vermeulen, D de Vocht and L van Puyenbroeck, o.c., p. 22-24.

${ }^{24}$ ECHR art 5(3) and art 6(3)(a). 
suspects and defendants by means of a 'Letter of Rights'. ${ }^{26}$ Subsequently a similar provision is found in the 2004 Proposal.

d) Content

- Accusations and Charges

Even though both article 5 and 6 ECHR are fairly specific in the information they require, such information is limited to factual information of the case, ie the reasons for the arrest and the nature and cause of the accusation and the respective legal bases. ${ }^{27}$ Information should be provided in a language the defendant understands. The amount of information available for the suspect or accused is strongly dependant on the nature and complexity of the case.

\section{- Procedural Rights}

Regrettably, there is no special provision in the ECHR requiring that the suspect should be notified immediately of the other defence rights listed in the Convention (eg the right to consult a lawyer, to examine or have examined witnesses, the right to interpretation and translation). According to the European Commission, however, it is important for both the investigating authorities and the persons being investigated to be fully aware of what rights exist. A Letter of Rights in a language the suspect understands does not create new rights but is an efficient way of informing suspects of their rights, which, according to the case law of the ECtHR, are not meant to be only theoretical but also effective in practice. Therefore article 14.3 of the Proposed Framework Decision required all Member States to 'ensure that police stations keep the text of the written notification in all the official Community languages so as to be able to offer an arrested person a copy in a language he understands'. From recent case law of the ECtHR it can be deduced that the State has a duty to take all reasonable steps to make a suspect fully aware of his rights of defence and that domestic authorities have to ensure actively that a suspect understands these rights. ${ }^{28}$

\section{- Information on the Investigation}

Article 6(3)(b) stipulates that anyone charged with a criminal offence is entitled to have adequate time and facilities for the preparation of his defence. These rights entail the right to have access to all elements that are useful to prepare the defence, ${ }^{29}$ including information à décharge (exculpatory), found by the prosecuting party. ${ }^{30}$

${ }^{26}$ European Commission, Green Paper on Procedural Safeguards for Suspects and Defendants in Criminal Proceedings throughout the European Union, COM(2003)75 final, Brussels, 19 February 2003, section 8.1 .

27 Ladent, Application No 11036/03, Judgment of 18 March 2008, 66; Ofner, Application No 524/59, Judgment of 19 December 1960.

28 Panovits, Application No 4268/04, Judgment of 11 December 2008 paras 68, 72; Talat Tunç, Application No 32432/96, Judgment of 27 March 2007 para 61; Padalov, Application No 54784/00, Judgment of 10 August 2006 paras 52-54.

29 Jespers, Application No 8403/78, Judgment of 14 December 1981.

30 Edwards, Application No 13071/87, Judgment of 16 December 1992 paras 35-38.

\section{CAMBRIDGE JUURNALS}


Nevertheless, the ECtHR has accepted public interest immunity may apply to certain elements: the right to full disclosure is not absolute and could, in pursuit of a legitimate aim such as the protection of national security or of vulnerable witnesses or sources of information, be subject to limitations. ${ }^{31}$ Any such restriction on the rights of the defence should, however, be strictly proportionate and counterbalanced by procedural safeguards adequate to compensate for the handicap imposed on the defence. The need for disclosure or non disclosure should at all times be under assessment by the trial judge. ${ }^{32}$

\section{Right to Legal Advice}

\section{a) Seek Legal Advice or Defend Oneself}

According to the European Commission, the right to legal advice is a second key element in the procedural rights for suspects. A suspect who is represented by a lawyer is in a far better position with regards to the enforcement of all his other rights, partly because he is better informed of those rights and partly because a lawyer will assist him in ensuring that his rights are respected. ${ }^{33}$ The right to legal assistance is covered by other European and international instruments as well: for instance the International Covenant on Civil and Political Rights ('ICCPR'), ${ }^{34}$ the Universal Declaration of Human Rights, ${ }^{35}$ the Charter on Fundamental Rights in the European Union, ${ }^{36}$ the American Convention on Human Rights, ${ }^{37}$ the African Charter on Human Rights and Peoples Rights ${ }^{38}$ and the 1990 UN resolution on Basic Principles on the Role of Lawyers. ${ }^{39}$

In the explanatory note on the 2004 Proposal, criminal proceedings were defined as 'all proceedings taking place within the European Union aiming to establish the guilt or innocence of a person suspected of having committed a criminal

31 Jasper, Application No 27052/95, Judgment of 16 February 2000 para 43.

${ }^{32}$ Rowe and Davis, Application No 28901/95, Judgment of 16 February 2000 para 58.

332003 Green Paper, s 4.1.

${ }^{34}$ Art 14(3)(b) and (d) ICCPR is similar to art 6 ECHR, but adds the right to be informed of the right to legal assistance.

${ }^{35}$ In art 11 of the Universal Declaration on Human Rights provides that everyone accused of having committed a crime, has the right to have all the guarantees necessary for his defence at his disposal.

${ }^{36}$ Charter of Fundamental Rights of the European Union, art 47 (Right to an effective remedy and to a fair trial).

${ }^{37}$ Art 8(2)(c)-(e) of the American Convention on Human Rights covers the same guarantees as art 6 ECHR, but adds the right 'to communicate freely and privately with his counsel'.

${ }^{38}$ The African Charter on Human Rights and Peoples Rights also guarantees in art 7(1)(c) the right to legal advice, including the right to be advised by a lawyer of his own choice.

${ }_{39}$ In this respect the UN General Assembly Resolution on 'Basic Principles on the Role of Lawyers' - initially adopted by the Eight Crime Congress, Havana, 7 September 1990, and then endorsed by UN General Assembly Resolution 45/121 of the General Assembly of the UN dated 14 December 1990 - is also of great importance. The ground rules of the rights and duties of lawyers are prescribed in this resolution, emphasising the obligation of the government to guarantee the independence of the legal profession. Freedom of speech and association and assembly of lawyers should be respected and governments have to recognise that the communication between lawyers and clients is confidential. The government also has to guarantee that lawyers have access to the file and information at the earliest possible stage in the proceedings. [do these instruments really say 'government', or 'State'?

\section{CAMBRIDGe JOURNALS}


offence or to decide on the outcome following a guilty plea in respect of a criminal charge' ${ }^{40}$ Legal advice before answering any questions in relation to the charge should protect the suspect against making statements without understanding the legal implications that he subsequently regrets. ${ }^{41}$

The right to legal advice/assistance is covered by article 6(3)(b) and (c) ECHR. Article 6 (3)(b) stipulates the right of every suspect to have the necessary time and facilities at his disposal to prepare his defence properly. The duration of this 'necessary time' is not specified as it is strongly dependant on the complexity of each individual case. However, assigning a new duty lawyer only a few hours before the start of the trial clearly violates the right to have the necessary time to prepare a defence. ${ }^{42}$ According to article 6(3)(c), the suspect has the right to choose either to defend himself (however he cannot be coerced into waiving his right to counsel), ${ }^{43}$ to be assisted by a lawyer of his own choosing (therefore the denial of legal assistance constitutes a violation ${ }^{44}$, as does the failure to allow confidential communication), ${ }^{45}$ or to have a lawyer assigned to him in case he does not have the means to pay for a lawyer himself. ${ }^{46}$ Article 6(3)(c) does not specify the manner of exercising this right. It thus leaves to the Contracting States the choice of the means of ensuring that it is secured in their judicial systems, the Court's task being only to ascertain whether the method they have chosen is consistent with the requirements of a fair trial. ${ }^{47}$

The right to seek legal representation does not constitute a waiver of the right to personal participation during the trial. The guarantees in article 6(3) ECHR are not an end in themselves, but must be interpreted in the light of their function in the overall context of the proceedings. ${ }^{48}$

\section{b) Obligation to Provide Legal Assistance}

Notwithstanding the fact that the suspect is entitled to defend himself, obligatory legal representation can be prescribed under certain circumstances, for example when an appeal is lodged. ${ }^{49}$ Article 3 of the 2004 Protocol addresses other circumstances, not mentioned in ECtHR case law in relation to obligatory legal advice, including the

402004 Proposal (n 3) s 32.

41 ibid s 55; also Salduz, Application No 36391/02, Judgment of 27 November 2008 Charter of Fundamental Rights of the European Union, OJ C, 18 December 2000, 364/1para 54.

42 Bogumil, Application No 35228/03, Judgment of 7 October 2008 para 48; Twalib, Judgment of 9 June 1998.

43 Yaremenko, Application No 32092/02, Judgment of 12 June 2008 para 81.

44 Panasenko, Application No 10418/03, Judgment of 22 July 2008 para 54; Shulepov, Application No 15435/03, Judgment of 26 June 2008 para 39.

45 Zagaria, Application No 58295/00, Judgment of 27 November 2007 para 36.

46 Timergaliyev, Application No 40631/02, Judgment of 11 November 2008 para 59; Padalov (n 25) paras 53-54.

47 Sannino, Application No 30961/03, Judgment of 27 April 2006 para 48.

48 Can, B 79, Judgment of 12 July 1984 para 48. 'The court sees it as its task to ascertain whether the proceedings considered as a whole were fair', which is standard case law of the ECtHR, see for example Kostovski, A 166, Judgment of 20 November 1989 para 39 and Edwards (n 27) para 34.

${ }_{49}$ Gillow, A 109, Judgment of 24 November 1986; Croissant, A 237-B, Judgment of 25 September 1992; Lagerblom, Application No 26891/95, Judgment of 14 January 2003.

\section{CAMBridge JOURNALS}


obligation to provide legal advice when the suspect is the subject of a EAW, extradition request or other surrender proceedings.

\section{c) Effective Legal Advice}

One of the basic obligations of a lawyer is to assist his client, not only in the preparation of the trial itself, but also in the control of the legality of any measures taken in the course of the investigation proceedings. ${ }^{50}$ Additionally, this legal assistance has to be effective and the State is under the obligation to ensure that the lawyer has the information necessary to conduct a proper defence. ${ }^{51}$ If legal representation is ineffective, the State is obliged to provide the suspect with another lawyer. ${ }^{52}$

Yet the ECtHR has clearly held that lawyer conduct is essentially an affair between the lawyer and his client. This is an important recognition by the ECtHR of the independence of the lawyer. ${ }^{53}$ This independence is threatened when the State is held responsible for every lawyer's shortcomings. The suspect should not be burdened with the risk of ineffective legal representation. Therefore the ECtHR has held that 'States are required to intervene only if a failure by counsel to provide effective representation is manifest or sufficiently brought to their attention'. ${ }^{54}$ The suspect does not have to prove that he has been prejudiced due to lack of effective legal assistance, ${ }^{55}$ nor is it necessary that damage has resulted. ${ }^{56}$

The suspect cannot be expected to assess the effectiveness of his legal representation himself; hence the need for Member States to introduce a monitoring system. This last provision is not stipulated in the ECHR, although the right to effective legal assistance can be deduced from ECtHR case law. ${ }^{57}$

\section{d) Contact and Consultation}

The right to legal representation - and thus to contact a legal advisor-arises immediately upon arrest, although a reasonable time is allowed for the lawyer to arrive. ${ }^{58}$ With regard to the moment the right arises, the proposed Framework Decision stipulated in article 2 that 'a suspected person had the right to legal advice as soon as possible and throughout the criminal proceedings if he wishes to receive it'. ${ }^{59}$

${ }^{50}$ Can (n 45); Öcalan, Application No 63486/00, Judgment of 4 March 2003.

51 Goddi, A 76, Judgment of 9 April 1984; Öcalan (n 47).

52 Artico, A 37, Judgment of 13 May 1980.

53 Imbrioscia, A 275, Judgment of 24 November 1993 para 41: 'However that may be, the applicant did not at the outset have the necessary legal support, but "a state cannot be held responsible for every shortcoming on the part of a lawyer appointed for legal purposes". (...) Owing to the legal professions' independence, the conduct of the defence is essentially a matter between the defendant and his representative; under Art. 6 (paragraph 3c) the contracting States are required to intervene only if a failure by counsel to provide effective representation is manifest or sufficiently brought to their attention'.

${ }^{54}$ Imbrioscia (n 50) para 41, Czekalla, Recueil/Reports 2002, Judgment of 10 October 2002 para 65; Bogumil (n 39).

${ }_{56}$ Alimena, A 195-D, Judgment of 19 February 1991.

57 T Spronken, G Vermeulen, D de Vocht and L van Puyenbroeck, o.c., p 30.

58 John Murray, Reports 1996-I, Judgment of 8 February 1996.

59 Commission Proposal for a council framework Decision on certain procedural rights in criminal proceedings throughout the European Union COM(2004)328 final (28 April 2004).

\section{CAMBridge JOURNALS}


No specification is made as to the circumstances in which consultation should be possible. The latter is not included expressis verbis in the ECHR, but is considered to be a part of the right in article $6 .{ }^{60}$ The ECtHR has elaborated on the consultation circumstances in its case law. It has ruled that fair trial was compromised when the consultation could only take place in the presence of a prison guard, ${ }^{61}$ in the presence of police officers ${ }^{62}$ or if a suspect can only communicate with his lawyer separated by a glass partition. ${ }^{63}$ Nevertheless, certain security measures could be allowed if proven truly necessary. ${ }^{64}$

\section{e) Legal Advice during Police Interrogation}

The physical presence of a lawyer can provide the necessary counterbalance against pressure used by the police during interviews. ${ }^{65}$ When the suspect has to make decisions during police interrogations that may be decisive for the further course of the proceedings, he has the right to consult a lawyer prior to these interrogations. ${ }^{66}$ Nevertheless, for years the ECtHR held that the right to have a lawyer present during police interrogation could in general not be derived from article 6(3) ECHR. ${ }^{67} \mathrm{In}$ contradiction to that initial view of the ECtHR, both the Yugoslavia Tribunal ${ }^{68}$ and the European Committee for the Prevention of Torture and Inhuman or Degrading Treatment or Punishment ('CPT') ${ }^{69}$ acknowledged that the right to have a lawyer present during police interrogation is one of the fundamental safeguards against illtreatment of detained persons. Subsequently this consideration was acknowledged in article 2 (2) of the 2004 Proposal.

${ }^{60}$ Can v Austria, Application No 9300/82, Judgment of 12 June 1984.

${ }^{6} S v$ Switzerland, Application No 13965/88, Judgment of 29 November 1991.

62 Rybacki, Application No 52479/99, Judgment of 13 January 2009 paras 53-62.

63 Oferta Plus SRL, Application No 14385/04, Judgment of 19 December 2006 paras 145-156; Castravet, Application No 23393/05, Judgment of 13 March 2007 paras 59-60.

${ }_{65}^{6}$ Lanz, Application No 24430/94, Judgment of 31 January 2002.

65 Magee, Application No 28135/95, Judgment of 6 June 2000 and Codron, Application No 35718/97, Judgment of 2 May 2000 para 60: 'The fact that an accused person who is questioned under caution is assured access to legal advice, and in the applicants' case the physical presence of a solicitor during police interview must be considered a particularly important safeguard for dispelling any compulsion to speak which may be inherent in the terms of the caution. For the court, particular caution is required when a domestic court seeks to attach weight to the fact that a person who is arrested in connection with a criminal offence and who has not been given access to a lawyer does not provide detailed responses when confronted with questions the answers to which may be incriminating.'

${ }_{66}$ Averill, Application No 36408/97, Judgment of 6 June 2000.

67 Dougan, Application No 44738/98, Judgment of 14 December 1999: 'Before the Court of Appeal they argued for the first time that the statements made by the applicant to the police should have been declared inadmissible on account of the absence of a solicitor during interview. However the merits of that argument must be tested against the circumstances of the case. Quite apart from the consideration that this line of defence should have been used at first instance, the Court considers that an applicant cannot rely on Art. 6 to claim the right to have a solicitor physically present during interview.' See also Brennan, Application No 39846/98, Judgment of 16 October 2001.

68 Statute of the International Tribunal for the former Yugoslavia (ICTY), art 18 (para 3). Decision on the Defence Motion to Exclude Evidence from ICTY in Zdravko Mucic, 2 September 1997, Case No IT-96-21-T, Trial Chamber II.

69 2nd General report (CPT/Inf (92) 3), ss 36-38.

\section{CAMBridge JOURNALS}


However, in two recent judgments the ECtHR has underlined the importance of the investigation stage for the preparation of the criminal proceedings, and referred to the recommendations of the CPT. The ECtHR further indicated that even where compelling reasons may exceptionally justify denial of access to a lawyer, such restriction may not unduly prejudice the rights of the accused. As a consequence, the ECtHR considers that the lack of legal assistance during a suspect's interrogation would constitute a restriction of defence rights, and that these rights will in principle be irretrievably prejudiced when incriminating statements, made during police interrogation without access to a lawyer, are used for a conviction. ${ }^{70}$

This new interpretation of article 6(3)(c), also referred to as the 'Salduz doctrine', has been confirmed in several judgments. In this (post-Salduz) case law the ECtHR has found member states (often Turkey) in breach of their Convention obligations by merely referring to the Salduz principle and adding that no exceptional circumstances were present that could justify an exception to this jurisprudence. ${ }^{71}$ Moreover, in the case of Shabelnik on 19 February 2009 the ECtHR took a clear stance regarding the interpretation that should be given to its new jurisprudence: '.. the applicant, having been warned about criminal liability for refusal to testify and at the same time having been informed about his right not to testify against himself, could have been confused, as he alleged, about his liability for refusal to testify, especially in the absence of legal advice during that interview'. ${ }^{72}$

\section{Right to legal assistance free of charge}

The right to free legal aid is not unconditional. Article 6(3)(c) ECHR stipulates that a suspect has the right to free legal aid on two conditions, namely (1) if he does not have sufficient means to pay for legal assistance and (2) when the interests of justice so require. The ECtHR has held that the suspect does not have to prove 'beyond all doubt' that he lacks the means to pay for his defence. ${ }^{73}$ The Proposed Framework Decision stipulated in article 5 that the costs of legal advice should be borne in whole or in part by the Member States if these costs would cause undue financial hardship to the suspected person or his dependents.

The ECtHR indicates three factors which should be taken into account: ${ }^{74}$

- The seriousness of the offence and the severity of the potential sentence;

- The complexity of the case;

- The social and personal situation of the defendant.

70 Salduz (n 38) para 54-55 and Panovits (n 25) paras 66 and 70-73. 'The Court finds that in order for the right to a fair trial to remain sufficiently "practical and effective" article $6 \S 1$ requires that, as a rule, access to a lawyer should be provided as from the first interrogation of a suspect by the police, unless it is demonstrated in the light of the particular circumstances of each case that there are compelling reasons to restrict this right.'

71 Böke and Kandemir, Application Nos 71912/01, 26968/02 and 36397/03, Judgment of 10 March 2009; Aba, Application Nos 7638/02 and 24146/04, Judgment of 3 March 2009; Aslan and Demir, Application Nos 38940/02 and 5197/03, Judgment of 17 February 2009; Oztürk, Application No 16500/04, Judgment of 17 February 2009.

${ }_{72}$ Shabelnik v Ukraine, Application No 16404/03, Judgment of 19 February 2009.

73 Pakelli, A 64, Judgment of 25 April 1983 para 34.

74 Quaranta, A 205, Judgment of 24 May 1991 para 35.

\section{CAMBRIDGE JUURNALS}


The right to free legal aid exists whenever the deprivation of liberty is at stake, ${ }^{75}$ narrowing down the definition of 'interests of justice'. Denying free legal aid for a period during which procedural acts, including when questioning of the applicants and their medical examination are carried out, is unacceptable according to the ECtHR. ${ }^{76}$

Member States are free to operate the system that appears to them to be the most effective as long as free legal advice remains available where the interests of justice demand it. ${ }^{77}$

\section{Right to Interpretation and Translation}

Suspects who do not speak or understand the language of the proceedings are clearly at a disadvantage. They are especially vulnerable, whatever their circumstances. Consequently, the right to interpretation and translation strikes the Commission as particularly important. ${ }^{78}$

a) The Scope of the Right to Interpretation and Translation

\section{- All parts of Criminal Proceedings}

The right to free interpretation is derived from article 5(2) and 6(3)(a)-(e) ECHR ${ }^{79}$ and established in ECtHR case law. ${ }^{80}$ It extends to all parts of the criminal proceedings, which means that Member States have to provide an interpreter as soon as possible after it has come to light that the suspect is in need of an interpreter. ${ }^{81}$ The fact that no 'registered' interpreter was present during an initial police interrogation does not compromise the right to a fair trial and interpretation, as long as the interpretation was sufficient in quality and scope. ${ }^{82}$ The ultimate duty to ensure fairness of the proceedings rests with the trial judge, ${ }^{83}$ since he is the ultimate guardian of the fairness of the proceedings. ${ }^{84}$ The 2004 Proposal referred to a competent authority being in charge of the decision regarding which documents need to be translated.

\section{- Translation of Written Documents}

The right to free translation of documents is not explicitly mentioned in article 6 ECHR. It is however established in ECtHR case law and incorporated by the European Commission in the 2004 Proposal. The ECtHR has held that only those documents

75 Benham, Reports 1996-III, Judgement of 10 June 1996.

76 Berlinski, Application Nos 27715/95 and 30209/96, Judgment of 20 June 2002.

772004 Proposal (n 3) s 60-61. 78 Green Paper, section 5.2.

79 This is also covered by art 14 para 3(a) and (f), ICCPR and arts 55 and 67 of the Rome Statute. The Rome Statute provides in art 55 the right to an interpreter and a translator for persons under investigation. Art 67 of the Rome Statute provides for interpretation and translation at trial.

${ }^{80}$ Luedicke, Belkacem and Koç. A 29, Judgment of 28 November 1978.

812004 Proposal (n 3) s 63.

82 Kamasinksi, A 168, Judgment of 19 December 1989 paras 76-77; See also the 2004 proposal (n 3) s 67.

83 Green Paper, section 5.2.1 (a).

84 Cuscani, Application No 32771/96, Judgment of 24 September 2002; Hermi, Application No 18114/02, Judgment of 18 October 2006 para 69-71.

\section{CAMBridge JOURNALS}


which the defendant 'needs to understand in order to have a fair trial' need to be translated:

The right, stated in paragraph 3 (e) of Art. 6 (Art. 6-3-e), to the free assistance of an interpreter applies not only to oral statements made at the trial hearing but also to documentary material and the pre-trial proceedings. Paragraph 3 (e) (Art. 6-3-e) signifies that a person "charged with a criminal offence" who cannot understand or speak the language used in court has the right to the free assistance of an interpreter for the translation or interpretation of all those documents or statements in the proceedings instituted against him which it is necessary for him to understand or to have rendered into the court's language in order to have the benefit of a fair trial (see the Luedicke, Belkacem and Koç judgment of 28 November 1978, Series A no. 29, p. 20, § 48).

However, paragraph 3 (e) (Art. 6-3-e) does not go so far as to require a written translation of all items of written evidence or official documents in the procedure. The interpretation assistance provided should be such as to enable the defendant to have knowledge of the case against him and to defend himself, notably by being able to put before the court his version of the events. ${ }^{85}$

The rules on how much material is to be translated vary according to the Member State and the nature of the case. According to the European Commission, this variation is acceptable as long as the proceedings remain 'fair'. ${ }^{86}$ The onus should be on the defence lawyer to ask for translations of any documents he considers necessary over and above what is provided by the prosecution. ${ }^{87}$

An indictment plays a crucial role in the criminal process, in that it is from the moment of its service that the defendant is formally put on written notice of the factual and legal basis of the charges against him. A defendant not conversant with the court's language may in fact be put at a disadvantage if he is not also provided with a written translation of the indictment in a language he understands. The fact that only the titles of the crimes alleged are translated, but not the material substance upon which the charges were grounded, does not necessarily constitute a breach of the right to information and interpretation, when the facts are not so complicated and an oral explanation sufficiently informs the accused of 'the nature and cause of the accusation against him', for the purposes of paragraph 3 (a) of article 6.88

\section{- Hearing or Speech Impairment}

The rights granted in article 6 can also require hearing aid during trial, when a persons' hearing impairment significantly reduces the ability to follow the proceedings. ${ }^{89}$

\section{b) Free Interpretation and Translation}

Both article 5(2) and 6(3) ECHR underscore the importance of the information being provided in a language the accused understands, with a right to free translation and interpretation. Similarly, articles 6 and 7 of the 2004 Proposal entail the right to free interpretation and the right to free translation of all relevant documents. ${ }^{90}$

${ }^{85}$ Kamasinksi (n 78); see also Lagerblom (n 46).

872004 Proposal (n 3) s 66.

89 Timergaliyev, Application No 40631/02, Judgment of 14 October 2008 para 60.

90 Luedicke, Application No 6210/73, Judgment of 28 November 1978.

\section{CAMBridge JOURNALS}


c) Accuracy of the Translation and Interpretation

The interpretation should enable the defendant's 'effective participation' in the proceedings. The proceedings should be recorded as a method of verifying that the interpretation was accurate. Recordings should not be used to challenge the proceedings from any other point of view. ${ }^{91}$

Whilst Member States are conscious of these obligations in theory, these are not fully complied with in practice. ${ }^{92}$ The difficulty however, is not one of acceptance on the part of the Member States, but one of levels and means of provision, and perhaps most importantly, costs of implementation. ${ }^{93}$

\section{- Registers of Translators and Interpreters}

In order to comply with the provision on accurate translation and interpretation, research ${ }^{94}$ has shown that a training system or translators is essential. The training system should focus on general practice of interpretation and translation and specific practice of the legal system. According to this research, Member States which currently do not have any training system should be required to develop one. As guaranteeing the quality of the training is of real importance, standards should be governed and accredited by an independent body. This accreditation must be renewed on a regular basis, to maintain skills and continuous professional development. Furthermore, a register should be made, listing all accredited interpreters and translators, and should be easily accessible to courts and legal practitioners. In this regard, it is important to stress that interpretation and translation are two different professions which should be treated accordingly. Consequently two different registers are required. ${ }^{95}$

\section{- Special Attention for Uncommon Languages}

Another difficulty is the translation and interpretation of uncommon languages. As the Green Paper stresses, it is for the Member States to make arrangements to cover such languages. ${ }^{96}$ Member States must make funds available to make court interpretation and translation a more attractive career option to language graduates. Also, law graduates with excellent language skills should be encouraged to join the profession and be offered appropriate training. ${ }^{97}$ Member States should also make an effort to recruit a sufficient number of translators and interpreters. ${ }^{98}$

912004 Proposal (n 3) s 69 and 70.

922004 Proposal (n 3) s 36-In some cases even a prisoner's cellmate is used as an interpreter. See also Reflection Forum on Multilingualism and Interpreter Training March 2009, <http://ec. europa.eu./commission_barosso/orban/docs/FinalL_Reflection_Forum_Report_en.pdf > .

93 Green Paper, s 5.2.

94 The research was carried out by the Lessius Hogeschool with the aid of a European Commission 'Grotius' subsidy (Grotius II project 2001/GRP/015); see also H Keijzer-Lambooy, WJ Gasille (eds) Instruments for Lifting Language Barriers in Intercultural Legal Proceedings EU project JAI/2003/AGIS/048 (ITV Hogeschool voor Tolken en Vertalers 2005).

${ }_{95}$ C Morgan, 'The Commission's draft proposal for a Framework Decision on certain procedural rights applying in proceedings in criminal matters throughout the European Union' in $\mathrm{H}$ Keijzer-Lambooy, WJ Gasille (eds), Instruments for Lifting Language Barriers in Intercultural Legal Proceedings 27-28. See also the Green Paper, s 5.2.2 (a).

96
98 Green Paper, s 5.2.2 (c).

97 Green Paper, s 5.2.2 (d).

\section{CAMBridge JDURNALS}




\section{B. Compliance with the ECHR in the EU Member States}

\section{The Right to Information}

In the study, 'the right to information' is dealt with as an overarching horizontal issue that is highly relevant for procedural rights being practical and effective. Two dimensions are distinguished. First, the right of anyone charged with a criminal offence to be informed on the nature and cause of the accusations against him and to have access to the evidence on which these accusations are based (as guaranteed by articles 5 and 6 ECHR). Secondly, the right to information in the sense of being informed on fundamental procedural rights, which as such is not covered by the ECHR.

A notable finding of the study is the fact that the right to remain silent is not a statutory right in France and Luxembourg and the right to have access to the file is not provided for on behalf of the suspect in legislation in Estonia, France, Germany and Spain. Both rights are basic requirements of a fair trial under the ECHR. And, with respect to all the rights that are the subject of the study (including the right to be informed on the charge), there is substantial divergence in the way suspects are informed as well as the absence of legal obligations for the authorities to inform the suspect on these fundamental procedural rights.

With regards to the right to contact a lawyer after arrest, all Member States have a legal obligation to inform the suspect of this right, but this information is not always given immediately after arrest. Also, the moment at which the obligation to inform the suspect of his right to have a lawyer present during police interrogation varies from promptly after arrest until a later stage in the investigation or proceedings. This right is obviously only effective when the suspect is given timely information of it and if he is offered the opportunity to contact a lawyer before the first police interrogation. In many Member States where there is a right to legal assistance during police interrogation, there are no provisions to secure the effectuation of this right.

The same applies to information on the right to legal aid. In four Member States (Belgium, Denmark, Luxembourg and Sweden) there is no legal obligation to inform the suspect of the right to legal assistance (partially) free of charge and in the remainder of the Member States where a legal obligation to inform the suspect does exist, the moment at which the duty arises varies considerably as well as the manner in which the information is given. In the majority of the countries the information is given orally and in only four countries is the information provided in a Letter of Rights (Austria, Czech Republic, Poland and Sweden).

A similar picture can be drawn with regard to information on the right to interpretation and translation. In nine Member States there is no legal obligation to inform the suspect on his right to interpretation (Bulgaria, Denmark, Estonia, Finland, France, Germany, Italy, Luxembourg and the Netherlands) and in eight Member States there is no obligation to inform the suspect on his right to translation (Denmark, Estonia, Finland, Germany, Italy, Luxembourg, the Netherlands and the United Kingdom).

Striking is that in Belgium and Finland there is no legal obligation to inform the suspect of his right to remain silent and in six Member States there is no obligation to inform the suspect of his right to call and examine witnesses (Belgium, Denmark, Finland, France, Greece and Luxembourg).

In ten Member States the suspect is informed about (one or more of) his rights by means of a Letter of Rights (Austria, Czech Republic, England and Wales, Italy, Latvia,

\section{CAMBRIDGE JUURNALS}


Luxemburg, Poland, Slovak Republic, Spain and Sweden). However, there are great differences between these EU Member States as to which rights are included. Many Letters of Rights do not mention the right to remain silent or the right to translation or interpretation and sometimes there is no Letter of Rights available in the language the suspect understands.

\section{The Right to Legal Assistance}

According to the case law of the ECtHR the right to contact a legal advisor-as part of the general right to legal assistance which is covered by article 6(3)(b) and (c) ECHRarises immediately upon arrest. The study shows that the right to contact a lawyer after arrest exists in most Member States. However, there is a great divergence as to the moment at which the right to contact a lawyer can be effected. For example, in a considerable number of countries this is not possible immediately after arrest-as required by the ECHR - but only at a given stage of the investigation or the proceedings.

Also, it follows from recent judgments of the ECtHR that access to a lawyer should as a rule be provided as from the first interrogation of a suspect by the police, unless it is demonstrated in the light of the particular circumstances of the case that there are compelling reasons to restrict this right. Furthermore, the ECtHR has held that the lack of legal assistance during a suspect's interrogation would constitute a restriction of his defence rights and that these rights will in principle be irretrievably prejudiced when incriminating statements made during police interrogation without access to a lawyer are used for a conviction.

It can be concluded from the study that the basic rules mentioned above are not common practice throughout the EU. The right to consult a lawyer before questioning is still not legally guaranteed in all Member States (eg Belgium) and in some Member States there is no right for the lawyer to be present at interrogations carried out by the police. In almost all countries where the lawyer is allowed to be present, authorities are obliged to inform the suspect of this right but there are considerable differences among Member States as to the moment at which the obligation to inform the suspect of this right arises and the way in which the information is provided to the suspect. Furthermore, in several Member States there is no possibility for the defence to deliberate in private during questioning. Finally, the study shows that the presence of a lawyer at the interrogation is not deemed indispensable: only in three Member States (Portugal, Spain and Italy) is it not allowed to use the confession of a suspect made in the absence of his lawyer as evidence in court.

\section{The Right to Legal Assistance (partially) Free of Charge}

With respect to the right to legal assistance (partially) free of charge - as guaranteed by article 6(3)(c) ECHR-it follows from the case law of the ECtHR that Member States have a certain margin of appreciation in choosing a system that appears to them to be most effective. However, free legal assistance should always be available where interests of justice demands it. The study shows that although the right to legal assistance (partially) free of charge exists in all Member States (with the exception of Germany) there are considerable differences in the implementation of this right. Especially striking

\section{CAMBridge JOURNALS}


is the wide variety in merits and/or means tests. Also important is the fact that in a small number of Member States there is no legal obligation to inform the suspect of his right to legal assistance (partially) free of charge.

Where this obligation does exist, there is considerable variation as to the scope of this obligation. Besides the differences in the applicable legal frameworks regulating the right to legal assistance free of charge, the study also shows enormous differences in financial recourses available for legal aid. The remarkably low budgets of some Member States raise the question whether, despite existing guarantees in the applicable legal framework, it is in - in everyday practice - in fact possible to effectuate the right to free legal assistance whenever the interest of justice demands it.

\section{Quality of Legal Assistance (partially) Free of Charge}

Although it is clear from the case law of the ECtHR that the lawyer's conduct is essentially an affair between the lawyer and his client, the State is under the obligation to ensure that legal assistance is actually effective, and should have some sort of monitoring system place to ensure that this is so. The study shows that in a considerable number of Member States there are no mechanisms to control the quality of legal assistance free of charge and - in other Member States - the authorities carrying out this kind of control vary widely. Consequently, there seems to be a substantial divergence in the way the quality of free legal assistance is controlled and ensured. Also, the 'special' requirements for the lawyer providing legal assistance free of charge are, in many cases, of a rather general nature and not limited to providing legal assistance free of charge. Moreover, in the majority of Member States the specialisation and the availability of the lawyer are not taken into account when deciding on which lawyer to appoint to a case. These findings raise the question whether the quality of legal assistance (partially) free of charge is in fact sufficiently guaranteed throughout the EU.

\section{The Right to Interpretation and Translation}

Although the right to interpretation exists in all Member States, the right to translation of documents is guaranteed in all but five Member States (Austria, Bulgaria, France, Latvia and Portugal). The analysis shows a great divergence regarding the implementation of these rights. This divergence specifically applies to the fact whether there is a legal obligation to be informed on these rights and to the scope of the rights. In five Member States there is no provision for interpretation at the consultation of the suspect with his lawyer (Bulgaria, Belgium, Latvia, Malta and Hungary) and some Member States have no provisions for suspects who are visually impaired or hearing impaired. There is also a considerable variety in what documents have to be provided to the suspect, and what documents are translated. It appears from the study that only a slight majority of the Member States provide a written translation of the charge, the detention order, or the final judgment. A Letter of Rights is only translated in four of the ten countries that provide for a letter of rights (Luxembourg, Slovak Republic, Spain and Italy). The results of the study show that on the level of practical implementation of the right to interpretation and translation there is a divergence with the requirements that derive from the case law of the ECtHR as summarised in paragraph 2.4 .

\section{CAMBRIDGE JOURNALS}




\section{Procedural Rights in the Mutual Recognition Instruments}

When comparing the results of the analysis between the various mutual recognition instruments, some main findings can be distinguished quite easily. First, the EAW clearly is the instrument that is treated the most as being equal to the domestic proceedings. The right to legal advice, for example, is applied to EAW proceedings in all Member States in the same way as for domestic cases. Secondly, conclusions as to the 'partial' application of certain rights with regards to mutual recognition instruments should be made with caution since some Member States have responded in this way when the particular instrument has not yet been implemented into national law. Thirdly, those Member States not applying certain rights with regards to the various mutual recognition instruments are often the same. Finally, the great majority of Member States apply the right to information on fundamental procedural guarantees to the mutual recognition proceedings equally as for domestic proceedings.

\section{THE EU'S POLICY ON PROCEDURAL RIGHTS IN CRIMINAL PROCEEDINGS}

The current basic framework of the EU regarding procedural rights in criminal proceedings consists of article 6 of the Treaty on European Union ('TEU') and the EU Charter of Fundamental Rights. Both documents explicitly refer to the acquis of the ECHR of the Council of Europe. Article 6 TEU provides that the Union shall respect fundamental rights, as guaranteed by the ECHR and as they result from the constitutional traditions common to Member States. The Charter of Fundamental Rights of the European Union includes several rights applicable to criminal proceedings such as the 'right to an effective remedy and a fair trial' (article 47) and 'the presumption of innocence and right of defence' (article 48). Moreover, article 53 states that 'in so far as this Charter contains rights which correspond to rights guaranteed by the Convention for the Protection of Human Rights and Fundamental Freedoms, the meaning and scope of those rights shall be the same as those laid down by the said Convention. This provision shall not prevent Union law providing more extensive protection'. As noted above, the Treaty of Lisbon has accorded the Charter legally binding force. ${ }^{99}$

The Commission stated in 2000 in a Communication to the Council and the European Parliament that 'it must therefore be ensured that the treatment of suspects and the rights of the defence would not only suffer from the implementation of the principle (of mutual recognition) but that the safeguards would even be improved through the process'. ${ }^{100}$ This conviction led to the drafting by the Commission of the 2004 Proposal referred to in the previous chapters. ${ }^{101}$ Emerging from the consultation process preceding the drafting of this proposal were five areas of priority rights: legal aid for suspects and defendants; the development of a 'letter of rights' to inform suspects which rights they could exercise; extra protection for 'vulnerable groups'; consular assistance; and translators and interpreters. Other subjects (such as bail, the principles of nemo tenetur

99 Declarations annexed to the final act of the intergovernmental conference which adopted the Treaty of Lisbon, signed on 13 December 2007 (OJ, 9 May 2008, C.115/337).

${ }^{100}$ Communcation to the Council and the European Parliament of 26 July 2000 on Mutual Recognition of Final Decisions in Criminal Matters (COM(2000)495 final, 29 July 2000).

1012004 Proposal (n 3).

\section{CAMBridge JOURNALS}


and ne bis in idem, fairness in the handling of evidence, appeal and trial in absentia) were reserved for 'further research'.

As negotiations developed, increasing opposition to the proposal emerged. Probably the main dividing line was the question whether the EU was competent to legislate on purely domestic proceedings or whether the legislation should be devoted only to crossborder cases. ${ }^{102}$ It is striking to note in this respect that this element did not prevent Member States from adopting a wide range of measures in the fight against crime, which also have direct implications for domestic law and domestic proceedings (eg common definitions on terrorist offences ${ }^{103}$ or minimum standards on maximum sentences for certain types of trafficking in persons). ${ }^{104}$ Nor was it an obstacle in 2001 for improving the standing of victims in criminal proceedings. ${ }^{105}$ In this context reference should also be made to article 82 of the Treaty on the Functioning of the European Union ('TFEU'), ${ }^{106}$ Pursuant to which directives establishing minimum rules should aim at facilitating mutual recognition of judgments and judicial decisions, and police and judicial cooperation in criminal matters. These minimum rules should concern, inter alia, mutual admissibility of evidence between Member States, the rights of individuals in criminal procedure and the rights of victims of crime. This competence of the EU is new, in the sense that criminal procedure had so far been left out of the scope of harmonisation (cf the wordings of article $31 \mathrm{TEU}$ ). Another common critique to the proposed framework decision was that the rights were too vague and set at too low a threshold or that the proposal would have added little value to the existing protections under the ECHR.

Eventually, no political agreement could be reached. ${ }^{107}$ The Commission however remained convinced of the need for EU action on this point. A Study carried out for the Commission by the Université Libre de Bruxelles (ULB) between 2007 and 2009 showed that almost all practitioners involved in cross-border proceedings consider an instrument of this sort to be essential. ${ }^{108}$

Finally, on 8 July 2009 the European Commission presented a new and much more limited draft for a Council Framework Decision on procedural rights. ${ }^{109}$ Unlike the previous proposal, this new draft only focuses on one set of rights, namely those relating to interpretation and translation. This new proposal is part of the new approach endorsed

102 Press release on the $2807^{\text {th }}$ Session of the Council on the 12 and 13 of June 2007.

103 Council Framework Decision of 13 June 2002 on combating terrorism, OJ L 164/3, 22.6.2002.

104 Council Framework Decision of 19 July 2002 on combating trafficking in human beings, OJ L 203/1, 1.8.2002.

105 Council Framework Decision of 15 March 2001 on the standing of victims in criminal proceedings, OJ L 82/1, 22.03.2001.

106 OJ. 9 May 2008, C 115, 47. With the coming into force of the Lisbon Treaty in 2009, the former Treaty establishing the European Community has been renamed as Treaty on the Functioning of the European Union (TFEU). Together with the new Treaty on the European Union (TEU), the TFEU constitutes the new foundation of the EU.

107 Even on a diluted version, Justice Ministers could not find any agreement at the Justice and Home Affairs Council on 19 to 20 April 2007. The proposal was discussed again by the Council on 13 June 2007. The Council was unable to agree and there the matter has lain since.

108 GVV Tiggelen and L Surano, Institute for European Studies, Université Libre de Bruxelles ECLAN-European Criminal Law Academic Network, Analysis of the Future of Mutual Recognition in Criminal Matters in the European Union, 20 November 2008, EC DG JLS.

109 COM(2009)338.

\section{CAMBridge JOURNALS}


by the EU in the field of minimum procedural guarantees in criminal proceedings. The preamble to the 2009 Council Resolution endorsing the Roadmap on procedural rights justifies this as follows: 'Bearing in mind the importance and complexity of these issues, it seems appropriate to address them in a step-by-step approach, whilst ensuring overall consistency.' In other words, the EU will follow a right-by-right approach, addressing future actions one area at a time.

Although the priority measures listed in the Roadmap are defined in a rather general way and seem to leave substantial room for interpretation, the preamble to the Resolution endorsing the Roadmap expressly states that any new EU legislative acts in this field should be consistent with the minimum standards set out by the Convention, as interpreted by the ECtHR. The significance hereof cannot be underestimated. It can be expected that the pressure on Member States to align their national rules with the ECtHR case law (cf for example the new jurisprudence on legal assistance before the first police interrogation $)^{110}$ will be sensibly increased.

As mentioned above, the Roadmap was incorporated in the Stockholm Programme of December 2009. In this Programme the European Council has invited the Commission to put forward the proposals in the Roadmap for swift implementation and to examine further elements of minimum procedural rights for suspected and accused persons. Following this step-by-step approach, the European Commission has already submitted proposals on two concrete measures. Firstly, a Directive on the right to interpretation and translation in criminal proceedings was adopted by the European Parliament and the Council on 7 October 2010. Secondly, in July 2010 a Proposal was launched for a Directive on the right to information in criminal proceedings. This initiative relates to the measures on 'legal advice and legal aid' of the Roadmap which aim to improve the situation of suspects by ensuring that these individuals receive proper access to qualified legal advice from the earliest stages of criminal proceedings and to the measure on 'communication with relatives, employers and consular authorities' which, in conjunction with the right of access to a lawyer, is one of the important safeguards against ill-treatment of detained persons. ${ }^{111}$

Finally it should be remarked that, whereas the Roadmap was originally intended to guarantee a minimum level of procedural protection throughout the EU in all criminal cases (cross-border as well as national); its application is limited to cross-border cases. Although this may seem - to some - a drawback, it is not. This approach offers an opportunity to introduce minimum EU standards in areas where such an exercise is needed, for instance in the field of cross-border traffic of evidence (eg the question which procedural safeguards should be respected in one Member States when executing a telephone tap at the request of another Member State). ${ }^{112}$

110 See (n 70).

111 Impact Assessment accompanying the Proposal for a Directive of the European Parliament and of the Council on the right to information in criminal proceedings (SEC(2011)686 final), Brussels, 8 June 2011, 5.

112 In 2009 the European Commission ordered a study on the laws of evidence in criminal proceedings throughout the European Union. This study concerned not only the international admissibility of evidence but also the future of cross-border evidence gathering between the Member States. The results of this study, carried out by the Institute for International Research on Criminal Policy of Ghent University, were published in 2010. See G Vermeulen, W De Bondt and Y Van Damme, EU cross-border gathering and use of evidence in criminal matters: Towards

\section{CAMBridge JOURNALS}


The realisation of minimum procedural rights for the defence in criminal proceedings throughout the EU is of high importance. It will increase mutual trust and confidence between Member States and thus pave the way for smoother judicial cooperation in criminal matters in the EU. It will also help to meet the obvious need to strengthen (and complement) the basic ECHR acquis. The results of a recent study clearly underline the need for EU action in this field. Although the four procedural rights that were the subject of the research - the right to information, the right to legal advice, the right to legal assistance (partially) free of charge and the right to interpretation and translation - seem to be guaranteed by law more or less in accordance with the ECHR in the criminal justice systems of the EU, a more in-depth look at the implementation of these rights raises doubts as to whether in all Member States everyday practice is in line with the Strasbourg standard. Particularly striking is the finding that fundamental rights such as the right to remain silent, to have access to the file and to call and/or examine witnesses or experts - all being basic requirements of a fair trial in the ECHR — are not provided for in the legislation of all Member States. Although discussion over the last few years of procedural rights in criminal proceedings within the context of the EU have not led to any concrete results, the topic has recently received increased attention. The new (legally binding) status of the EU Charter of Fundamental Rights, the endorsement of the Roadmap on Procedural Rights by the Council in November 2009 and the incorporation of the Roadmap in the Stockholm Programme, are all significant steps in the right direction. It now has to be awaited if this renewed ambition will prove a lasting one. An adequate protection of suspects and defendants in criminal proceedings throughout the EU will however not be reached only by the endorsement of binding framework decisions on a number of basic procedural guarantees such as the right to interpretation and translation and the right to legal assistance. These measures should go hand in hand with an effort to introduce EU wide standards in the field of cross-border evidence gathering and mutual admissibility of evidence in criminal proceedings. Only then will the subject of a criminal investigation be guaranteed a minimum level of protection in the whole EU, irrespective of the cross-border or national character of the investigation.

Laurens van Puyenbroeck* and Gert Vermeulen**

mutual recognition of investigative measures and free movement of evidence? (AntwerpenApeldoorn-Portland 2010) 254.

* Assistant at the department of Penal Law and Criminology at the University of Ghent; Attorney of law at the bar of Ghent.

** Professor of Criminal law, Head of the Department of Criminal Law and Criminology and Director of the Institute for International Research on Criminal Policy (IRCP) at Ghent University. Extraordinary Professor of Evidence Law at Maastricht University.

\section{CAMBridge JOURNALS}

